\title{
Pavle Horvat u kontekstu slovensko-hrvatskih političkih odnosa od 1918. do 1945. i njegova književna obrada
}

\author{
BARBARA RIMAN \\ Inštitut za narodnostna vprašanja \\ Ljubljana, Slovenija \\ barbara.riman@guest.arnes \\ KRISTINA RIMAN \\ Fakultet za odgojne i obrazovne znanosti Sveučilišta u Puli \\ Pula, Hrvatska \\ kriman@unipu.hr
}

\begin{abstract}
U radu se prikazuje djelovanje Pavla Horvata, Slovenca koji je bio aktivan u kontekstu povijesno-političkih događanja prije svega u vrijeme Drugoga svjetskog rata u Hrvatskoj. O njegovu životu i djelovanju ne zna se mnogo. U radu se donose nove informacije o njegovu političkom djelovanju, posebice na temelju napisa u slovenskom tisku, a potom se ta saznanja uspoređuju s književnom obradom istoimenoga lika u romanu Fara sv. Ivana (Župa sv. Ivana) autora Miška Kranjca.
\end{abstract}

Ključne riječi: Pavle Horvat; Slovenci u Hrvatskoj; Drugi svjetski rat; Miško Kranjec

\section{Uvod}

Povijest slovenstva i Slovenaca u Hrvatskoj još je uvijek relativno slabo istražena, iako postoji određeno zanimanje za tu temu. Na hrvatskim je prostorima, u različitim povijesnim periodima, djelovao niz osoba slovenskoga podrijetla. Iako su mnoge od njih bile važne za vrijeme u kojem su živjele, u suvremenoj hrvatskoj i slovenskoj historiografiji više nisu posebno istaknute. ${ }^{1}$

\footnotetext{
1 Ne postoji biografski leksikon osoba slovenskoga podrijetla koje su djelovale u Hrvatskoj, ali neki su slovenski povjesničari u svojim radovima pokušali uputiti na slovenske intelektualce koji su bili intenzivno uključeni u hrvatski javni i kulturni život. Više vidi u: KRŽIŠNIK-BUKIĆ, „Znameniti Slovenci na Hrvaškem skozi zgodovino”, 421-445; HEĆIMOVIĆ, BARBIERI, NEUBAUER, Slovenski umjetnici na hrvatskim pozornicama; GANTAR GODINA, „Slovenski intele-
} 
Jedan od vidljivijih i aktivnijih bio je i Pavle ${ }^{2}$ Horvat, koji je svoju javnu političku karijeru započeo u Sloveniji, ali je ostavio traga u slovenskoj i hrvatskoj povijesti zbog svojega djelovanja u Zagrebu tijekom Drugoga svjetskog rata.

O Pavlu Horvatu i njegovu djelovanju danas se ne zna mnogo, a pozornost privlači jer je prikazan poput lika u romanu Fara sv. Ivana (Župa sv. Ivana) slovenskoga pisca Miška Kranjca. Horvat je povijesna osoba koja je imala određeni utjecaj u kontekstu političko-povijesnih događaja utoliko što ga je hrvatsko političko vodstvo tijekom Drugoga svjetskog rata vidjelo kao nekoga tko bi eventualno mogao djelovati u smjeru povezivanja Slovenaca i Hrvata. U hrvatskoj je povijesti ostao zabilježen kao osoba uključena u organizaciju i zaštitu Slovenaca koji su Drugi svjetski rat dočekali i proživjeli u Zagrebu. Dio tih zagrebačkih Slovenaca bili su i pojedinci koji su iz slovenskih krajeva bili protjerani ili su pak sami pobjegli. O Horvatu postoje podaci koje usputno donose hrvatski i slovenski povjesničari, a na temelju njih dolazi se do zaključka da se radi o specifičnoj osobi koja je uglavnom prikazivana u negativnom kontekstu i u dokumentarističkim tekstovima i u književnosti.

U radu se stoga, na temelju svjedočanstava u objavljenim dokumentima te podataka iz slovenskih novina, rekonstruira društveno-političko djelovanje Pavla Horvata. Njegov se rad uspoređuje s književnom obradom istoimenoga lika u romanu Miška Kranjca Fara sv. Ivana.

\section{O Pavlu Horvatu u znanstvenim, stručnim i publicističkim tekstovima}

Pavla Horvata povjesničari rijetko spominju u svojim radovima, ${ }^{3}$ uglavnom u kontekstu suradnje $s$ visokim dužnosnicima i političarima tijekom Drugoga svjetskog rata na prostoru Hrvatske. Iako je u tom periodu bio najvidljiviji u javnosti, njegova je politička djelatnost započela neposredno nakon Prvoga svjetskog rata.

O Horvatu i njegovu radu teško je pisati jer u slovenskim (a i hrvatskim i jugoslavenskim) biografskim leksikonima i enciklopedijama nema zabilježenih podataka o njegovu životu. Nažalost, ne mogu se navesti ni osnovni biografski podaci kao što su godina i mjesto rođenja i smrti.

Horvatovo političko djelovanje može se rekonstruirati do određene mjere isključivo pomoću novinskih napisa i sagledavajući ga u kontekstu političkih i društvenih događanja u Sloveniji, a zatim i u Hrvatskoj.

ktualci - izseljenci na Hrvaškem”; GANTAR GODINA, „Slovenski izobraženci na Hrvaškem od 1850 do 1960”; GANTAR GODINA, „Slovenski izobraženci na Hrvaškem po letu 1868” itd.

2 U izvorima pronalazimo obje inačice imena, Pavel i Pavle. Odlučile smo se za oblik Pavle (osim u citatima) jer je to u duhu hrvatskoga jezika.

3 KRIZMAN, Ustaše i Treći Reich, 47; KARAKAŠ OBRADOV, Novi mozaici nacija, 207; KARAKAŠ OBRADOV, „Migracije Slovencev na hrvaško območje”, 148-149. 
Početak njegova političkoga djelovanja zabilježen je u Mariborskom delav$c u, u$ kojem je evidentirano da je "student Pavle Horvat” ni mimohod prema trgu" ${ }^{\text {u }} \mathrm{u}$ sklopu proslave ustanka i oslobođenja u Prekomurju 18. kolovoza 1919. godine. Sljedeći podatak o njemu donose slovenske Novine pišući o orlovskoj organizaciji, ${ }^{6}$ pri čemu ga se ističe kao „okružnoga predsjednika” koji je biranim riječima govorio o „orlovskim organizacijama i njihovim ciljevima”. ${ }^{8}$ Njegov veliki entuzijazam u članku je dočaran njegovim riječima poticanja članstva: „Radimo za vjeru i Narod, tako ćemo doseći orlovski cilj. Bog vas poživio."

Iz navedenih izvora stječe se dojam da je Pavle Horvat mladić pun entuzijazma koji se želi ostvariti u javnom životu za dobrobit zajednice. Međutim, napis u novinama objavljen godinu poslije baca drukčije svjetlo na njegove namjere. U tekstu u kojem se poziva na oslobađanje župnika Klekla, ${ }^{10}$ kojega je zatvorila mađarska vlada, među ostalim stoji: „Pavle Horvat, nekadašnji pokrajinski poglavar u Murskoj Soboti, prouzročio je da mađarske vojne vlasti zatvore g. Klekla kada je jednoga dana početkom ožujka 1920. išao u Št. Gothard iz dušobrižničkih razloga."11 Vjerojatno je to učinio zbog političkoga rivalstva i nepodržavanja djelovanja svećenika Jožefa Klekla, ${ }^{12}$ vrlo aktivnoga političara naklonjenog idejama Antona Korošca i njegove Slovenske ljudske stranke (SLS), koja je bila vrlo moćna u Prekomurju. ${ }^{13}$

4 „... visokošolec Pavle Horvat...” („Prekmurje”, Mariborski delavec /Maribor/, 20. 8. 1919., 2).

5 „veličastni izprevod proti trgu” (Isto).

6 Orlovske organizacije bile su društva koja su promicala važnost tjelovježbe $s$ idejom da omladina „duševno i tjelesno ojača i pripremi se za teške narodne i kulturne bitke uz pomoć tjelovježbe". U Sloveniji su s radom započela početkom XX. stoljeća. Društva nisu bila važna samo zbog tjelovježbe, nego su bila važan element u nacionalnom, kulturnom i političkom smislu. Njihovo djelovanje bilo je povezano s nastupanjem u javnosti. U usporedbi sa sokolskim društvima, gdje je primarni cilj bila tjelovježba, cilj orlovskoga pokreta bio je širi te je imao i određenu dozu klerikalizma (ROZMAN, „Orlovski odsek na Vrhniki”, 165).

7 „Okrožnog predsednika” („Orlovski tečaj v Betlincih”, Novine /Murska Sobota/, 18. 1. 1920., 3 ; „Orlovske organizacije združenje i njihovoga namena”).

8 Isto.

9 „Delajmo za vero i Narod, tak dosegnemo namen Orlovski. Bog Vas Živi” („Orlovska Okrožna", Novine, 23. 5. 1920., 3).

${ }^{10}$ Jožef Klekl bio je svećenik, pisac i političar. Rođen je 13. listopada 1874. u Krajini u Prekomurju, a umro je 30. svibnja 1948. u Murskoj Soboti. Školovao se u Lendavi i Kisegu, a bogosloviju je završio u Sambotelu. Djelovao je u različitim župama u Prekomurju. Pokrenuo je časopis Marijin list (1904. - 1941.) i Novine (1913. - 1941.). Politički je bio vrlo aktivan, i to prije svega u Prekomurju. Bio je član SLS-a, na čijem je čelu bio Anton Korošec. Prije svega je djelovao kao svećenik te u smjeru očuvanja slovenstva u Prekomurju (ŠLEBINGER, „Klekl, Jožef”).

${ }_{11}$ „Ko je nekega dne v začetku marca 1920 šel v mesto Št. Gothard iz dušnopastirskih razlogov, je Pavel Horvat, nekdanji okrajni glavar v Murski Soboti, povzročil pri madjarski vojni oblasti, da so g. Klekla zaprli” („Za osvoboditev župnika Klekla”, Slovenec /Ljubljana/, 9. 2. 1921., 2).

12 Više o toj temi vidi u: PERŠAK, „Anton Korošec in slovensko-hrvaška nasprotja v Prekmurju", 133-150.

${ }_{13}$ Politički život u Prekomurju nakon Prvoga svjetskog rata bio je vrlo živ. Novi teritorij priključen Kraljevini Jugoslaviji bio je vrlo plodno područje za širenje ideja različitih političkih stranaka koje su propagandom pokušavale doći do novih članova i glasova. Osim slovenskih 
Promatrajući političku scenu u Sloveniji nakon Prvoga svjetskog rata i povezujući ju s kasnijim nastojanjima Pavla Horvata, neke se situacije čine jasnijima. To se u prvom redu odnosi na vezu između Stjepana Radića i Hrvatske seljačke stranke (HSS) te slovenske javne politike. Ta se „mačkovska” politika, kako je nazivana u slovenskoj javnosti tridesetih godina XX. stoljeća, već dvadesetih godina, a i poslije, može povezivati s djelovanjem Pavla Horvata. Naime, težnje Stjepana Radića bile su proširiti idejne ciljeve i utjecaj njegove stranke i na susjedne zemlje. Svoj je utjecaj nastojao usmjeriti na Prekomurje, gdje se Horvat i upoznao s političkim ciljevima HSS-a, a potom i na područja istočne Slovenije: Belu krajinu, brežički kraj, okolicu Krškoga i dr. Vodeće slovenske stranke nisu prihvatile ideje HSS-a iz različitih razloga, ali je utjecaj ideologije HSS-a u Sloveniji ostao i nije nikada sasvim nestao. I nakon smrti Stjepana Radića u Sloveniji je bilo osoba i skupina, osobito u istočnim krajevima, koje su simpatizirale ideje HSS-a. To je prije svega bilo vidljivo tridesetih godina XX. stoljeća, kada je slovensko „mačkovstvo” ponovo postalo činjenični politički subjekt. ${ }^{14}$ Jedan od tih simpatizera koji nikada nije odustao od politike HSS-a bio je upravo Pavle Horvat.

Svoje političko djelovanje Horvat je usmjeravao prema organiziranju različitih kulturnih i političkih skupova ili sudjelovanju u delegacijama koje su politički djelovale u Prekomurju. ${ }^{15}$ Međutim, njegovo javno i političko djelovanje često je izazivalo i neugodne situacije, o kojima je tisak također izvještavao. U srpnju 1923. objavljena je vijest o fizičkom sukobu u kojem je sudjelovao Horvat sa svojim pristašama, pri čemu je bio ozbiljno ranjen. Različiti izvori donose različite podatke o broju i vrsti ozljeda koje je u tom sukobu zadobio („Ullen je četiri puta klepio Pavla Horvata, bivšega općinskog tajnika, koji sada sa smrću bojuje”; 16 „Ulen Matija iz Bratonaca napao je g. Horvata te mu nožem zadao tri smrtne rane..."17), ali se slažu da je Horvatovo stanje teško. Horvat se ipak oporavio i nastavio svoj javni rad. Tako je u tisku 1924. objavljeno da je sudjelovao u proslavi povodom pete godišnjice oslobođenja Prekomurja, ${ }^{18}$ a sudjelovao je i u utemeljenju Središnje narodne knjižnice u Prekomurju. ${ }^{19}$

stranaka, u Prekomurju su svoje mjesto tražili i članovi Hrvatske republikanske seljačke stranke. Postoji mogućnost da je već tada Pavle Horvat vidio svoju mogućnost uključivanja na hrvatsku političku scenu (KUZMIČ, „Stranke v Prekmurju med obema vojnama”, 58-60).

14 PRUNK, „Radić in Slovenci 1919-1928”, 33-34.

15 „Spravišče SLS v M. Soboti”, Novine, 7. 5. 1922., 1; „Lendava ostane pri Jugoslaviji”, Murska straža (Gornja Radgona), 17. 8. 1922., 3; „Lendava ostane pri Jugoslaviji”, Glasilo KSK jednote (Toronto), 6. 9. 1922., 6.

16 „Ullen je štirikrat smekno Pavla Horvata bivšega občinskoga tajnika, ki se zdaj s smrtjov vojuje” („Bratonci”, Novine, 15. 7. 1923., 3).

17 „Ulen Matija iz Bratonc je napadel g. Horvata ter mu zadal z nožem tri smrtne rane...” („Beltinci”, Murska straža, 19. 7. 1923., 3).

18 „Proslava petletnice osvobojenca Prekmurja”, Tabor (Maribor), 5. 7. 1924., 1.

19 „Ustanovitev Centralne ljudske knjižnice”, Tabor, 5. 12. 1924., 1. 
Nepovoljni napisi o Pavlu Horvatu pojavili su se u tisku i u obliku oglasa u kojima je objavljivano da Horvat nema pravo zastupati „parobrodarsko društvo Norddeutscher Lloyd u Donjoj Lendavi" u njihovim poslovima jer ga je "generalno zastupništvo u Zagrebu otpustilo". ${ }^{20}$ Ta je objava imala i epilog jer je Horvat protiv pisca, urednika, izdavača i tiskara Novina iz Maribora podnio tužbu zbog klevete, koju je i dobio, te je vijest o tome bila objavljena. ${ }^{21}$

Horvata susrećemo i kao člana Zveze slovenskih kmetov (Savez slovenskih seljaka), ali daje mu se i etiketa „kasniji mačekovac”, što znači da ga je njegovo djelovanje i povezivanje s politikom Vladka Mačeka zapravo i obilježilo. ${ }^{22}$ Upravo zato što nije bio prihvaćen u slovenskoj politici vjerojatno je svoju priliku vidio u suradnji s hrvatskim političarima. Pretpostavlja se da je nakon Prvoga svjetskog rata, zbog političkih veza, u Prekomurju upoznao ljude koji su mu mogli pomoći, odnosno u njemu su vidjeli osobu koja im može pomoći u ostvarenju vlastitih ciljeva.

Negativni odjeci u medijima povezani s njegovim djelovanjem nastavljaju se i dalje. Desetljeće poslije, u kontekstu formiranja političkih stranaka u Sloveniji, slovenski je tisak obavještavao o tome da je formirana politička stranka u Sloveniji koju podupire i dr. Maček. Obrušili su se na Pavla Horvata te su njegovo dotadašnje djelovanje prikazali u negativnom svjetlu. Naglasili su da je njegova politička stranka već treća skupina u Sloveniji koja tvrdi da ima potporu dr. Mačeka. ${ }^{23}$

Naime, Horvat je iskoristio različita mišljenja koja su prije Drugoga svjetskog rata imali istaknutiji slovenski političari, koji su zapravo po određenim političkim opcijama zagovarali ideje slične HSS-ovim. Politika dr. Mačeka i HSS-a u slovenskom se javnom i političkom životu tada nazivala "mačkovstvo” te se naglašavalo da „kao hrvatski politički pokret - kod nas Slovenaca nema nikakva smisla jer ono našim slovenskim političkim ciljevima neće previše pomoći. Zato je svatko tko je za 'mačkovstvo' izdajica vlastitoga naroda! Naš voditelj jest i može biti samo dr. Anton Korošec i nitko drugi!”24

U tom neslaganju slovenskih klerikalaca s idejama HSS-a Horvat je vidio priliku za vlastiti veći politički angažman. Ivan Kreft o tome piše ovako: „Sve drugačije ponašala se takozvana štajerska opozicija Slovenske kmečke stranke [Slovenska seljačka stranka] koju je vodio Pavle Horvat. Njemu je vodstvo SKS-a u Ljubljani bilo premalo 'mačkovsko', pa ga je u Zagrebu tužakao sve

\footnotetext{
20 „generalno zastopstvo v Zagrebi odpustilo” („Zastopstvo parobrodarskoga društva”, Novine, 10. 11. 1929., 4).

${ }^{21}$ „Tiskovna tožba proti piscu”, Jutro (Ljubljana), 2. 4. 1930., 2; „Tiskovna tožba proti piscu”, Domovina (Ljubljana), 10. 4. 1930., 10.

22 VIDOVIČ-MIKLAVČIČ, „Zveza slovenskih kmetov v letih 1932-1935”, 564.

23 „Tri skupine, ki hočejo biti podružnice HSS”, Jutro, 8. 2. 1940., 7.

24 „kot hrvaško politično gibanje - pri nas Slovencih nima nobenega smisla, ker ono nam naših slovenskih političnih ciljev ne bo pomagalo doseči Zato je vsak, kdor je za mačkovstvo, proti slovenstvu, proti našim političnim ciljem! Vsak slovenski mačkovec je Izdajalec lastnega naroda! Naš voditelj je in more biti samo dr. Anton Korošec in nihče drugi” („Minister dr. Kulovec o važnosti sedanjih volitev", Ponedeljski Slovenec /Ljubljana/, 21. 11. 1938., 1-2).
} 
dok od samoga Mačeka nije dobio punomoć da može mimo SKS-a organizirati Mačekov pokret u Sloveniji." ${ }^{25}$

U novinskom zapisu iz ožujka 1940. navodi se još jedna obavijest o Horvatovim akcijama, koje su uključivale zborovanje „slovenskih pristaša dr. Vladka Mačeka”, u kojem je nakon obavijesti o održanom zbivanju iznesen i kritički komentar:

„Ne želimo se upuštati u kritiku tih navoda, koji zvuče vrlo ambiciozno, samo zaključujemo da g. Horvat u kratkom razdoblju od pet godina već treći put ulazi u tako opsežne političke akcije. Još uvijek nam je u sjećanju njegovo strastveno djelovanje iz 1935. u korist Narodne stranke dr. Hodžera. I tadašnje bombastične prognoze gospodina Pavla Horvata da će Sloveniju preplaviti 'plave majce' pokazale su se kao jalov i neozbiljan pokušaj. Tri godine poslije vidjeli smo g. Horvata na kandidacijskoj listi dr. Mačeka. Sada g. Horvat započinje treći put, oslanjajući se, kako voli isticati, na pristanak Zagreba i dr. Mačeka. Ako imamo informacije iz pouzdanoga izvora, i ova je njegova objava, na koju se poziva, rođena u njegovoj političkoj mašti te nema nikakve osnove u Zagrebu." ${ }^{26}$

Napominje se da se on sada okrenuo hrvatskoj politici jer nije uspio ni $\mathrm{u}$ jednoj slovenskoj stranci. Ističe se da je „... gospodin Horvat torbario po Zagrebu” 27 te da zapravo „... pomoću nekih autoriteta izvan Slovenije najavljuje nastup svoje političke organizacije $"{ }^{28}$ Među ostalim, slovenske su novine zaključile da je „taj čovjek, barem što se tiče njegove političke kičme, pokazao da zna vrlo spretno, i to bez koristi, mijenjati boje te se podređivati svim vrstama 'vođa'...". 29

25 „Vse drugače se je obnašala takoimenovana ‘štajerska opozicija' Slovenske kmečke stranke, ki jo je vodil Pavel Horvat. Temu je bilo vodstvo SKS v Ljubljani vse premalo mačkovsko, pa ga je v Zagrebu tako tožakal, dokler ni dobil od samega Mačka pooblastila, da lahko mimo SKS organizira Mačkovo gibanje v Sloveniji” (KREFT, „Špeharjev obračun z Mačkovo politiko v Sloveniji”, Dolenjski list /Novo Mesto/, 16. 7. 1954., 7).

${ }^{26}$ „Ne da bi se hoteli spuščati v kritiko teh navedb, ki zvenijo neverjetno širokopotezno, samo ugotavljamo, da se g. Horvat v kratkem razdobju petih let že tretjič loteva tako širokopotezne političke akcije. V spominu nam je še njegovo vneto delovanje iz leta 1935 za dr. Hodžerovu narodno stranko. Tudi takrat se je gromovitost napovedi gosp. Pavla Horvata češ da bodo Slovenijo preplavile 'modre srajce', sprevrla v jalov in neresen poskus. Tri let kasneje smo že videli g. Horvata na kandidatni listi dr. Mačka. Zdaj pričenja g. Horvat že v tretje, opirajoč se, kot tako rad poudarja, na pristanek Zagreba in dr. Mačka. V kolikor pa smo iz zanesljivega vira poučeni, je tudi ta njegova legitimacija, na katero se sklicuje, porojena v njegovi politični domišljiji ter nima v Zagrebu nobene osnove” ("Akcija Pavla Horvata”, Mariborski večernik „Jutra”/Maribor/, 2. 3. 1940., 2).

${ }^{27}$ „... gospod Horvat krošnjaril po Zagrebu...” („Iz domaće politike”, Slovenska zemlja /Ljubljana/, 13. 6. 1940., 4).

${ }^{28}$ „... s pomočjo nekih avtoritet preko meje Slovenije proglaša nastop svoje politične organizacije” („V borbo za programe, ne v mehanični boj za glasove”, Večernik/Ljubljana/, 22.-25. 3. 1940., 3).

${ }^{29}$ „... ta mož, vsaj kar se tiče njegove politične hrbtenice, pokazal da zna spretno, pa vendar brez haska, spreminjati barve in se podrejati vseh vrst 'voditeljem'..” („Slovenska kmetijskodelavska sloga”, Slovenski dom /Ljubljana/, 16. 6. 1940., 3). 
Očito je Pavle Horvat bio osoba koja je po svaku cijenu željela stupiti u politiku, a ta mu se mogućnost otvorila 1941., kada je Kraljevina Jugoslavija ušla u Drugi svjetski rat. Kao predsjednik Slovenske kmečko-delavske sloge (Slovenska seljačko-radnička sloga), Horvat je vidio kako se razvija situacija u Hrvatskoj te pravodobno reagirao. Tako je već 12. travnja 1941. u Hrvatskom narodu objavio Razglasitev slovenskemu narodu te pozvao Slovence da se pridruže „hrvatskom narodnom pokretu“. ${ }^{30}$ Tekst je završio riječima da slovenski narod dijeli sudbinu hrvatskoga naroda, s kojim ga „povezuje povijest”. ${ }^{11}$ Istovremeno je Slovenska kmečko-delavska sloga na brojnim mjestima u Zagrebu postavila plakate na slovenskom jeziku kojima je pozivala Slovence neka se prijave u to društvo.

Slovenske su novine zabilježile da je Horvat u svoju Slovensku kmečkodelavsku slogu upisao sve zagrebačke Slovence koji su mu se javili, a koje je pozvao preko zagrebačke radijske stanice. Zaključeno je da je „svojim odlučnim nastupom spriječio mnoge nejasnoće što se tiče daljnje sudbine Slovenaca u hrvatskoj državi”32 te da je njegovo udruženje postalo „... općenarodno zastupništvo naših ljudi u hrvatskoj državi!"33 To je vrlo važno, pogotovo ako se uzme u obzir da su neka druga slovenska društva dobila zabranu djelovanja. ${ }^{34}$ Tako je Pavle Horvat, prilagođavajući se, zajedno s članovima toga društva uspio osigurati postojanje barem jedne institucije koja je bila prijateljska za Slovence koji su se našli u Zagrebu, a koju su prihvaćali i novi politički krugovi. Iako su ti članci izlazili u novinama koje su prihvaćale tadašnje političke vlasti, pa napise u njima moramo uzeti s određenom rezervom, svejedno se čini da su svi imali velika očekivanja od Slovenske kmečko-delavske sloge.

Društvo je djelovalo u tom smjeru te se čini da je zahvaljujući dobrom odnosu s tadašnjim ministrom vanjskih poslova Mladenom Lorkovićem Pavlu Horvatu uspjelo zaposliti određeni broj Slovenaca u različitim konzularnim predstavništvima Nezavisne Države Hrvatske (NDH): u Grazu, Ljubljani i Beogradu, a poslije i Trstu. Članovi Slovenske kmečko-delavske sloge bili su, osim Slovenaca koji su ostali u Zagrebu, prognanici i izbjeglice. ${ }^{35}$

\footnotetext{
${ }^{30}$ „... hrvaškega narodnega gibanja...” (KARAKAŠ OBRADOV, „Migracije Slovencev na hrvaško območje”, 148).

31 Isto.

32 „S svojim odločnim nastopom je preprečil marsikatero negotovost glede nadaljnje usode Slovencev v hrvatski državi” („Slovenska organizacija v hrvatski državi”, Jutro, 1. 8. 1941., 3; „Slovenska kmečka delavska sloga v Zagrebu”, Karawanken Bote /Krainburg = Kranj/, 9. 8. 1941., 5; „V Zagrebu je društvo Slovenska kmečkodelavska sloga”, Domovina in Kmetijski list / Ljubljana/, 7. 8. 1941., 8).

${ }^{33}$ „... splošno-narodna zastopnica naših ljudi v hrvatski držav!” („Slovenska organizacija v hrvatski državi”, Jutro, 1. 8. 1941., 3).

34 Međuraće je sa stanovišta slovenskoga udruživanja označeno kao zlatno razdoblje, a slovenska kulturna i prosvjetna društva bila su zabilježena u različitim gradovima u Hrvatskoj. Najviše slovenskih društava djelovalo je u Zagrebu, ali do početka Drugoga svjetskog rata neka su prestala s djelovanjem zbog različitih razloga (smanjenje članstva, problem financiranja i dr.), a neka su bila zabranjena (RIMAN, „Slovenska društva u Hrvatskoj”, 101-129).

${ }^{35}$ „Vprizoritev Cankarjeve 'Lepe Vide’ v Zagrebu”, Jutro, 13. 12. 1941., 5.
} 
Na Horvatovu inicijativu osnovana je i zadruga Triglav, koja se bavila otkupom voća i povrća te ga izvozila u Treći Reich. Ujedno je ta zadruga i posredovala, pa je mnoge Slovence poslala na rad u Treći Reich, čime ih je neizravno vratila u njihov zavičaj. Slovenska kmečko-delavska sloga djelovala je i kao posrednička ustanova preko koje se određeni broj prognanih Slovenaca i slovenskih svećenika ipak uspio vratiti svojem domu. ${ }^{36}$

Politički smjer djelovanja Slovenske kmečko-delavske sloge vidi se iz ideje Pavla Horvata da se prostor od Bele krajine pa do Zidanog Mosta pripoji $\mathrm{NDH}$, a nakon kapitulacije Italije zagovarao je ideju da se i Ljubljanska pokrajina pripoji NDH. Tako su Horvat i njegovi suradnici 17. rujna 1943., nakon kapitulacije Kraljevine Italije, poslali Anti Paveliću molbu da se pri vodstvu Trećega Reicha zauzme za „... ujedinjenje cijeloga slovenskog teritorija...” ${ }^{37}$ te da se osnuje državna veza između NDH i Slovenije. ${ }^{38}$ No, Horvatova je uloga u tome upitna. Slovenski povjesničar Boris Mlakar piše o Pavlu Horvatu te smatra da prema postojećim izvorima nije moguće tvrditi da je ideja o hrvatsko-slovenskoj državnoj uniji njegova, iako naglašava da je doista činio mnogo toga u približavanju Hrvata i Slovenaca. ${ }^{39}$

O tome svjedoči i Vladimir Židovec. O odnosima političkoga vrha NDH i Pavla Horvata Židovec je odgovarao tijekom ispitivanja 1947. godine. On se s Horvatom susretao prije svega kao pročelnik Općega odjela Ministarstva vanjskih poslova NDH. Tijekom osam mjeseci, koliko je Židovec obavljao „upravno-činovnički posao”, bilo mu je povjereno i „vođenje poslova sa Slovencima, tj. s Pavlom Horvatom" ${ }^{40}$ Govoreći o svojoj suradnji s Horvatom, Židovec je naglasio da je njegova važnost pala nakon kapitulacije Italije, kada je Pavelić shvatio da je ideja o ujedinjenju koju je Horvat spominjao zapravo samo fantazija. Iako je Horvat izgubio svaku važnost, i dalje se za svaki slučaj s njim održavala veza, ali „Horvatove političke fantazije nisu bile zanimljive”. ${ }^{41}$

Dalje kaže da ga je Edvard Kardelj, koji je u proljeće 1942. došao u Zagreb, spomenuo kao vođu Slovenske kmečko-delavske sloge te, iako nema dokaza, smatra da je „Horvat provokator, koji prema van nastupa na liniji Oslobodilačke fronte”. Druga informacija o Horvatu dolazi od belogardističkoga kapelana Jake Mavca. Smatrao je da je Pavle Horvat bio jedan od rijetkih Slovenaca u Zagrebu kojega su ustaše uspjeli pridobiti na suradnju. ${ }^{42}$

\footnotetext{
36 KARAKAŠ OBRADOV, Novi mozaici nacija, 206.

${ }^{37}$ „... združevanje celotnega slovenskega ozemlja...” (KARAKAŠ OBRADOV, „Migracije Slovencev na hrvaško območje”, 149).

38 Isto.

${ }^{39}$ MLAKAR, „Ustaši in slovenska protirevolucija”, 365; MLAKAR, „Nekaj podatkov k razjasnitvi stikov med slovenskim protirevolucionarnim vodstvom in Zagrebom”, 141-150.

40 ŽIDOVEC, Pavelićev diplomat na jugoistoku Europe, 424.

41 Isto.

${ }^{42}$ MLAKAR, „Ustaši in slovenska protirevolucija”, 366.
} 
Iako je Horvat u prvom redu nastojao djelovati na prostoru Slovenije, tragovi njegova djelovanja ostali su sačuvani u hrvatskim dokumentima. Među sačuvanim spisima Ministarstva vanjskih poslova NDH nalaze se priznanice ministra Mehmeda Alajbegovića koje se odnose na tajni fond njegova ministarstva.

Za potrebe ovoga rada izdvojili smo svjedočenje koje se odnosi na dogovore koje je ministar (po naputku poglavnika) imao s Horvatom:

„Kod preuzimanja ministarstva vanjskih poslova Mladen Lorković mi je saopćio da se iz tajnog fonda isplaćuju honorari Pavlu Horvatu koji radi na zbliženju Slovenaca i Hrvata. Kad sam kasnije upoznao Pavla Horvata, on mi je opisao svoju djelatnost na zbliženju hrvatskog i slovenskog naroda i skrenuo mi pažnju na promemorije koje je on nakon 10. travnja 1941. godine u ime svoje i još neke grupe Slovenaca predao Paveliću. Taj Horvat živio je u Zagrebu i često putovao u Sloveniju, a ranije bio zastupnik HSS u Sloveniji." ${ }^{33}$

Na temelju toga svjedočenja može se zaključiti da je Horvatovo djelovanje u političkim zbivanjima u međuratnom i ratnom razdoblju bilo diskretno jer je primao naknadu za političko djelovanje, koje, po svemu sudeći, nije urodilo rezultatom na koji se računalo.

„Kasnije sam pitao Pavelića, da li mu je poznat slučaj Horvata, a on mi je odgovorio da je upoznat s time, da Horvatu treba i nadalje isplaćivati honorar, te da je sa Horvatom povezan Štitić kod ravnateljstva za javni red i sigurnost i da on nadzire njegov rad. Štitić mi je kasnije objasnio da Horvat radi medu Slovencima u Zagrebu i Sloveniji, da mu i on isplaćuje neki honorar, ali da nema potpuno povjerenje u Horvata i potrebno je čvršće kontrolirati njegov rad što se i čini, kako ne bi mogao Horvat bez razloga trošiti državni novac. Iz tajnog fonda M.V.P. isplaćivano je Horvatu 1944. godine mjesečno oko 50 hiljada kuna, a kasnije su ti iznosi povišeni, na temelju naloga poglavnika. Pavle Horvat je tražio da mu se isplati 10 miliona kuna odjedanput, ali je poglavnik odredio da mu se ta suma postepeno isplaćuje kroz godinu dana. Ja nisam primao od Horvata izvještaje o radu i smatram da je on te izvještaje podnašao Blašku Štitiću ili Paveliću. Jednom zgodom Horvat mi je spomenuo da će mu izgleda uspjeti povezati jednu grupu ljudi, koji nešto znače u Sloveniji u svoju akciju. Vjerojatno da je tih 10 miliona tražio u tu svrhu, a Pavelić je odobrio da mu se ista postepeno isplaćuje, kako bi mogao kontrolirati rad Horvata i čvršće ga vezati uza se." ${ }^{44}$

Iz navedenoga proizlazi da je Horvat doista i u hrvatskim političkim krugovima bio osoba kojoj suradnici nisu vjerovali te su pronalazili načina da ga kontroliraju. Toj karakterizaciji ide u prilog i drugi dokument koji Krizman navodi, a odnosi se na istražni elaborat u kojem Vladimir Židovec obrađuje pitanje ustaških pregovora sa Slovencima neposredno prije sloma NDH:

\footnotetext{
${ }^{43}$ KRIZMAN, Ustaše i Treći Reich, 47.

44 Isto, 47-48.
} 
„U posljednje vrijeme $\mathrm{NDH}$, među ostalim pokušajima koji su činjeni u to doba, pojavljuje se i plan da se nešto učini zajedno sa Slovencima. Sigurno je inspiraciju za tu ideju dala pomisao da Slovenci moraju imati već nekakve veze sa Englezima i Amerikancima, jer da čitavu njihovu potajnu djelatnost dirigira Krek iz Rima.

Po izvještajima konzula iz Ljubljane prof. Baljića proizlazilo je da Slovenci takve veze doista imaju, a to se slagalo i s raznim glasinama koje su se o tome čule. Sjećam se da je i meni neki Horvat u par navrata spominjao da Krek, u sporazumu s Englezima i kraljem Petrom doista vodi u Sloveniji tajnu akciju kojoj je cilj da se dovede do angloameričke intervencije na jugoslovenskom području. Taj je Horvat bio na čelu nekakve stranke ('kmetsko-delavske') koja da ima u programu usku suradnju s Hrvatima, pa da je on još za banovine radio s dr. Mačekom. Ne poznajem doduše slovenski politički život, ali sam čuo da taj Horvat nikad nije imao neko političko značenje. No on se je dosta vrzao po Zagrebu za sve vrijeme NDH. Stvorio je čak neki plan o hrvatsko-slovenskoj 'državnoj zvezi', bio s time kod dr. Pavelića i sl. No to je već druga tema.

Kažem druga tema, jer u posljednje vrijeme NDH Horvat više nije imao nikakav ugled ni kod mjerodavnih hrvatskih političara, kako sam to mogao iz raznih primjedaba razabrati. Sigurno sam to opazio čim sam postao pročelnik općeg odjela (u rujnu 1944 god.). Dr. Alajbegović mi je tada rekao da mogu namjestiti kao ugovorne činovnike kod predstavništva NDH u Trstu, Ljubljani, Mariboru i Gracu one ljude koje bude predlagao taj Horvat, ali sam odmah vidio da on to smatra jednom običnom izvanjskom koncesijom tom čovjeku, dok mu u biti ne pridaje baš nikakvo političko značenje." ${ }^{45}$

Nakon Drugoga svjetskog rata Pavle Horvat pobjegao je u inozemstvo. Čini se da je otišao u Austriju, gdje je nastavio svoje političko djelovanje među slovenskim izbjeglicama. Njegov stan u Zagrebu dan je za potrebe repatrijacije Slovenaca, ${ }^{46}$ pa taj podatak baca dodatno negativno svjetlo na Horvatovo djelovanje.

Potrebno je spomenuti da ni u Austriji Horvat nije bio dobro prihvaćen. Naime, zabilježeno je da je Horvatova ideja bila osnovati seljačku uniju, ali: „Slovenski izbjeglicama odlučno se ne slažu s osnivanjem seljačke unije izbjeglica u kojoj bi Slovence predstavljao g. Pavle Horvat iz Prekomurja. Takvu mu legitimaciju mi slovenski izbjeglice ne damo jer mu ne vjerujemo zbog njegove prošlosti. Ona je takva da ne možemo vjerovati da bi g. Horvat u seljačkoj uniji doista zastupao prije svega zajedničke interese izbjeglica, za njih radio i žrtvovao se." ${ }^{47}$

\footnotetext{
45 Isto, 287.

46 KARAKAŠ OBRADOV, „Migracije Slovencev na hrvaško območje”, 150.

${ }^{47}$ „V eni stvari slovenski begunci odločno ne soglašamo z ustanovljenjem kmečke unije beguncev, da bi namreč Slovence v njej zastopal g. Pavle Horvat iz Prekmurja. Te legitimacije slovenski begunci njemu ne damo, ker mu ne zaupamo, zaradi njegove prošlosti. Ta pa je taka, da ne moremo verovati, da bi gospod Horvat v kmečki uniji res iskal prvenstveno skupne koristi beguncev, zanje delal in se žrtvoval” („Begunsko pismo s Koroške”, Ameriška domovina /Cleveland/, 31. 8. 1948., 9).
} 


\section{Pavle Horvat u romanu Miška Kranjca ${ }^{48}$}

Vrijeme između dva svjetska rata te neposredno poraće razdoblje je u kojem nastaje niz tendencioznih djela u književnosti koja su, premda često sadržavaju umjetnički vrijedne dijelove, duboko protkana političkim i društvenim. Jednim od takvih razdoblja u slovenskoj književnosti Slodnjak ${ }^{49}$ smatra vrijeme od tridesetih do pedesetih godina XX. stoljeća. Književnost smatra sredstvom socijalnoga prosvjeda, obnove i socijalističke izgradnje, te kao glavne značajke razdoblja iznosi da su tadašnji autori pri stvaranju, upravo iz društvenih razloga, više uzimali u obzir utilitaristička nego umjetnička pitanja. Dolazi do previranja u uredništvima časopisa, koji su mijenjali uređivačke politike, države su opterećene gospodarskom krizom koja je dovela do opće nezaposlenosti, veze među narodima prekidaju se, snovi o jednakosti europskih naroda i njihovu združivanju raspadaju se pred ratnom opasnošću. Slovenci su pritom još od 1918. u stalnom strahu od gubitka nacionalne individualnosti zbog prijetećega fašizma i nacionalsocijalizma, zbog čega rješenje traže u radikalnom socijalizmu ili komunizmu. U takvim je slovenskim književno-povijesnim okolnostima djelovao Miško Kranjec, prozaik koji se najdosljednije i najbrže razvijao u skladu s društveno-političkim trenutkom, odnosno promišljao je i novi oblik socijalne, odnosno radničke umjetnosti..$^{50}$

${ }^{48}$ Miško Kranjec rođen je u Velikoj Polani u Prekomurju. Nakon osnovne škole gimnaziju je završio u Ljubljani. Već kao učenik objavljivao je tekstove u različitim časopisima, pri čemu iskazuje bliskost s katoličkim strujanjima. Nakon gimnazije upisao je slavistiku na Sveučilištu u Ljubljani, ali studij nije dovršio. Sve se više posvećuje pisanju, pri čemu se odmiče od dotadašnje sklonosti katoličkom tisku i promišlja socijalna pitanja prisutna u njegovoj okolini te se zbližava s vodećim intelektualcima i komunistima, čiji su mu stavovi bili bliski. Pisao je pripovijetke i romane, bio je jedan od utemeljitelja časopisa Ljudska pravica. U međuratnom razdoblju vodio je pokret otpora protiv mađarske vlasti u Prekomurju i drugim dijelovima Slovenije. Nakon rata bio je urednik časopisa Ljudska pravica, direktor Cankarjeve založbe i Slovenskega knjižnega zavoda te glavni urednik Prešernove družbe i predsjednik izdavačkog savjeta DZS. U dva je navrata bio predsjednik Društva slovenskih književnika. Godine 1953. postao je član SAZU. Dvaput je dobio Prešernovu nagradu. Umro je u Ljubljani i sahranjen u rodnom mjestu (ZADRAVEC, Miško Kranjec). Danas je Miško Kranjec u slovenskoj književnoj historiografiji poznat kao prekomurski autor koji je u svojim djelima oslikao veliki broj karaktera koje je smjestio u njemu najpoznatiju slovensku pokrajinu. Pišući u maniri socijalnoga realizma, koji je u slovenskoj književnosti najprisutniji od tridesetih do pedesetih godina XX. stoljeća, danas se prepoznaje kao najplodniji autor toga pravca i razdoblja. Navodeći veliki broj Kranjčevih romana, Slodnjak se osvrće i na roman Fara sv. Ivana. Prepoznaje ga kao djelo u kojem je Kranjec donekle popravio umjetničke nedostatke iz svoje prethodne faze, u kojoj objavljuje romane s partizanskim motivima (SLODNJAK, Slovensko slovstvo, 476-477).

49 SLODNJAK, Slovensko slovstvo.

50 Slodnjak njegov razvoj opisuje na sljedeći način: „Od jednostavna i osjećajna glasnika domaćega kraja i njegovih stanovnika naglo se razvija u upozoravajućega i optužujućega realista te se nakon Drugoga svjetskog rata nakratko našao čak i među socijalističkim književnim propagandistima, nakon čega je ponovo počeo tražiti umjetničke slobode, posebno u dječjoj i memoarskoj tematici.” - „Iz preprostega in čustvenega glasnika domače zemlje in njenih prebivalcev se je naglo razvijal v svarečega in obtožujočega realista ter je po drugi svetovni vojni za kratko dobo pristal celo med socialističnimi slovstvenimi propagandisti, nakar je spet začel iskati umeniške osvoboditve, posebno $\mathrm{v}$ otroški in memoarski tematiki” (Isto, 414). 
U romanu Fara sv. Ivana (Župa sv. Ivana), u kojem je Kranjec na temelju stvarne osobe oblikovao književni lik Pavla Horvata, prikazuje se i analizira život pojedinih stanovnika Župe sv. Ivana u Slovenskim goricama u Štajerskoj, „slovenskogoričkih poluobrazovanih te domaćih i doklaćenih političkih špekulanata". ${ }^{11}$ Zbivanja u romanu usko su vezana uz društveno-politička događanja na prostoru Slovenije i, djelomično, Hrvatske u vrijeme početka Drugoga svjetskog rata. S obzirom na to da su brojne ideje (i ideologije) nalazile svoje mjesto u književnim tekstovima, zanimalo nas je koje je događaje Kranjec procijenio relevantnima kao polazište za oblikovanje svojega romana, a osobito smjernice na temelju kojih bi se mogli sagledati određeni politički ili društveni odnosi u tom romanu. Pritom smo se vodili postavkom Inge Crosman Wimmers, prema kojoj se tema književnoga djela ne svodi samo na tekst, nego prelazi svoje granice tako što čitatelj sa svojim semantičkim kompleksom, odnosno obzorom očekivanja, nadograđuje ono što se nalazi u tekstu. ${ }^{52}$ Prožimanjem autorova i čitateljskoga obzora očekivanja odvija se tematizacija. Čitatelj aktivno sudjeluje u rekonstrukciji priče tako što će svojim životnim iskustvom (iskustvom izvanknjiževne stvarnosti) konkretizirati priču. Pojedini motivi i karakteri iz književne stvarnosti Kranjčeva romana omogućuju upravo takav sraz teksta i čitatelja u kojem smo, u prvom redu, željeli propitati slovensko-hrvatske odnose i mogućnosti njihove interpretacije iz perspektive suvremenoga čitatelja.

$\mathrm{Na}$ samom početku romana autor donosi podatke kojima romanu daje element dokumentarnosti. To se u prvom redu odnosi na lik Matije Klemenca, koji dolazi u gostionicu u Župi sv. Ivana i procjenjuje njezine stanovnike na temelju časopisa Jutro ${ }^{53}$ i Slovenec ${ }^{54}$, koji su dostupni posjetiteljima gostionice. Kranjec se u romanu referira i na relevantne naslove (i autore) iz vremena kada se radnja romana zbiva. Tako nabraja Jožu Kerenčiča ${ }^{55}$ i njegovo djelo

\footnotetext{
${ }^{51}, \ldots$ slovenjgoriških polizobražencev ter domačih in pritepenih političnih špekulantov" (Isto, 476-477).

${ }^{52}$ PELEŠ, Tumačenje romana, 191.

${ }^{53}$ Jutro je bilo jedan od najčitanijih slovenskih političkih dnevnika. Izlazilo je od 1920. do 1945. u Ljubljani. Kao glasilo mlade liberalne Samostojne demokratske stranke (Samostalna demokratska stranka), svojim se tekstovima zauzimalo za jugoslavenski državni centralizam. U opstanku Jugoslavije vidjeli su jamstvo za narodni opstanak i kulturni razvoj te su polemizirali s katolički usmjerenim časopisima. Program Jutra bio je blizak građanstvu, službenicima, učiteljima, pripadnicima sokolskih organizacija i trgovcima (AMON, Vloga slovenskega časopisja, 20-21).

${ }^{54}$ Slovenec je izlazio od 1873. do 1945. godine. Osnovan je da bi simpatizere slovenske katoličke političke misli potaknuo na aktivno političko djelovanje. U početku je izlazio kao tjednik, a od 1883. kao dnevnik. Godine 1907. list je postao glasilo SLS-a (prije Katoličke narodne stranke). Zagovarao je autoritet Crkve (Isto, 22-23).

${ }^{55}$ Jože Kerenčič (1913. - 1941.) rođen je u seoskoj obitelji u Jastrebcima u Slovenskim goricama. Osnovnu školu polazio je u Kogu, a školovanje je nastavio u Mariboru, gdje se uključio u napredni omladinski pokret. Na Filozofskom fakultetu u Ljubljani studirao je pedagogiju i slavistiku. Učlanio se u Komunističku partiju i djelovao u naprednom studentskom pokretu naprednom studentskom gibanju. Nakon što je diplomirao neko je vrijeme bio nezaposlen, a kada je dobio posao u školi u Gornjoj Radgoni, rad mu je otežavala činjenica da je bio osumnjičen za komunističko djelovanje. Oko sebe je sakupio omladinu, koju je usmjeravao ljevičarski. Na-
} 
Zemljiški odnosi v Jeruzalemskih goricah ${ }^{56}$ (Zemljišni odnosi u Jeruzalemskim goricama), Kontrolora Škrobara ${ }^{57}$ autora Alojza Kraighera ${ }^{58}$, djelo Ignaca Koprivca $^{59}$ Kmetje včeraj in danes $^{60}$ (Seljaci jučer i danas) te pjesme Edvarda Kocbeka. ${ }^{61}$ Time se Kranjec poziva na iskustvo svojega pretpostavljenog čitatelja i na određeni mu način nudi mogućnost poistovjećivanja i razumijevanja političkoga identiteta pojedinih karaktera opisanih u romanu. Poistovjećujući očekivanja lika u romanu s očekivanjima koja od romana imaju čitatelji, autor dodatno naglašava i važnost navedenih tekstova i autora za cjelokupno razumijevanje života i mentaliteta ljudi na prostoru Slovenskih gorica. Pritom se vjerodostojnost prikazanoga ne odnosi samo na roman Miška Kranjca nego i na spomenute autore, njegove suvremenike.

kon kapitulacije Jugoslavije organizirao je pokret otpora. Nijemci su ga zbog njegova djelovanja zatvorili i pogubili u prosincu 1941. godine. Kerenčič se bavio i književnim radom. Pisao je romane, u kojima je obrađivao socijalnu problematiku sela, te sociološke i znanstvene studije (ŠULIGOJ, „Socialni pravičnosti posvečeno življenje in delo”, 373-390).

56 Ova Kerenčičeva rasprava tiskana je u Mariboru 1939. godine. Kerenčič u njoj navodi podatke kojima potvrđuje da je agrarna kriza u Sloveniji u najvećoj mjeri utjecala na vinogradarske krajeve. Pritom naglašava vlasničku i socijalnu strukturu, koja je presudna za teškoće s kojima se susreće seosko stanovništvo Jeruzalemskih gorica (ILEŠIČ, Novi prispevki k proučevanju socialnih problemov, 185-187), što je književno obradio Miško Kranjec u romanu Fara sv. Ivana.

${ }^{57}$ Ovaj je Kraigherov roman objavljen 1914. godine. U romanu je prikazao moralno propadanje slovenskoga činovništva u predratnim narodnim borbama i otpadništvo uopće te je na taj način prikazivao brojna ljubavna iskustva svojega junaka. Autor je u sljedećem izdanju, objavljenom 1950., roman pokušao označiti kao politički (SLODNJAK, Slovensko slovstvo, 325).

${ }^{58}$ Alojz Kraigher (1877. - 1959.) rođen je u Postojni, gdje je završio osnovnu školu. Gimnaziju je polazio u Novom Mestu i Ljubljani. Studij medicine završio je u Beču, nakon čega je radio u Ljubljani, Bovecu te u Sv. Trojici u Slovenskim goricama. Studirao je stomatologiju u Münchenu i bio zubar u Gorici, a zatim se pred fašizmom povukao u Ljubljanu. Bio je član Komunističke partije. Tijekom Drugoga svjetskog rata bio je u logoru Dachau. Nakon rata postao je bibliotekar Centralne medicinske knjižnice, gdje je radio do umirovljenja. Pisanjem se počeo baviti u gimnaziji. Pisao je dramska i prozna djela u kojima opisuje društvenu i političku situaciju prije Prvoga svjetskog rata, život slovenskih gradskih intelektualaca i malograđana, a važni motivi su mu ljubav i erotika te politička borba za očuvanje slovenstva. Djela su mu prevedena na hrvatski, češki, poljski i njemački (ŽEBOVEC, Slovenski književniki rojeni do leta 1899, 189-190).

${ }^{59}$ Ignac Koprivec (pravim imenom Ignac Ljubec, 1907. - 1980.) rođen je u Drbetincima. Neredovito se školovao zbog loših materijalnih prilika. Školovao se uz rad, pa je tako privatno završio srednju tehničku školu i polazio Filozofski fakultet, gdje je izvanredno studirao slavistiku. Kao student, priklonio se ljevičarima udruženima u akademsko društvo „Mladi Triglav”. Bio je publicist i književnik i uključio se u radnički pokret pod vodstvom Komunističke partije. Tijekom Drugoga svjetskog rata bio je u partizanima. Djelovao je kao slobodni književnik (PLAHUTA, „Koprivec, Ignac”).

${ }^{60}$ Zbirka crtica koje prikazuju Slovenske gorice objavljena je 1914. u četiri dijela raspoređena po godišnjim dobima. U djelu je naglasak na prikazu života i socijalnih odnosa među seljaštvom, međutim u njega je uklopljena i čitava lepeza narodnih običaja, koji danas tekst čine i mogućim etnografskim izvorom (VURNIK, „In memoriam: Ignac Koprivec”, 129-131).

${ }^{61}$ Edvard Kocbek (1904. - 1981.) slovenski je književnik i prevoditelj. Nakon završenoga studija romanistike u Ljubljani bio je gimnazijski profesor u Hrvatskoj i Sloveniji. Prvu pjesničku zbirku objavio je 1934. godine. Prevodio je djela francuskih prozaika (H. de Balzaca, G. de Maupassanta, P. Mériméea i dr.). Kocbekova proza s početka pedesetih godina utjecala je na slovensku suvremenu prozu („,Kocbek, Edvard”). 
Slične postupke Kranjec koristi i za oslikavanje sredine koju opisuje. Kada Matija Klemenc sa ženom Gizom prvi put dolazi u seosku gostionicu, prvo što primjećuje, osim slike kralja Aleksandra i kralja Petra, jesu časopisi Slovenec, Slovenski gospodar ${ }^{62}$ i Domoljub. ${ }^{63}$

Osim što je u romanu navodio stvarne časopise i knjige, isto je učinio is osobama. To je postupak kojem je Kranjec pribjegavao i u ostalim romanima. Franc Zadravec u monografiji o Mišku Kranjcu navodi njegovo promišljanje odnosa između umjetnosti, fikcije i istinitosti u umjetnosti, pri čemu smatra da umjetnost precizno prikazuje životnu istinu i da je njezin najneposredniji medij. ${ }^{64}$ Činjenica je da realistička poetika preferira prenošenje motiva iz stvarnoga svijeta u književni tekst, pa Kranjec u ovom romanu detaljno opisuje slovenskoga političara Pavla Horvata.

Već iz prvih rečenica kojima Kranjec opisuje Horvata jasno je da mu je autor nesklon. Ne dovodeći u pitanje utjecaj koji je Horvat imao u svojoj okolini, stavljajući riječ politik (političar) u navodnike, Kranjec iskazuje kritiku Horvatova političkoga djelovanja, priznajući mu staž u politici, ali isto tako naglašavajući njegovu tajnovitost. Njegovo ponašanje u politici povezuje s njegovim karakterom, koji nadalje povezuje s mentalitetom prostora u kojem je stasao:

„Poznavao je Pavla Horvata, kao što su ga poznavali gotovo svi ljudi u Slovenskim goricama i po Prekomurju. Nije se sjećao gdje se prvi put susreo s njim, znao je samo da su na 'ti' te da su 'stari' znanci. Taj čudni, najtajanstveniji slovenski 'političar' imao je već tada svojevrstan, i to ne slab, utjecaj na neke ljude. Bio je čovjek srednjih godina, gotovo još mlad ili barem mladolik, a politikom se bavio još od onoga rata, najprije u Prekomurju, odakle je bio rodom, potom u Slovenskim goricama, gdje se oženio u Malu Nedelju i gdje je imao svoju kuću.”65

Horvat je bio političar koji se tek marginalno javlja prije svega u slovenskom međuratnom političkom životu te na hrvatskoj političkoj sceni tijekom Drugoga svjetskog rata. O tome piše i Kranjec:

„Njegova politika uvijek je išla nekim sporednim putovima, iako se rado vrtio oko velikih, važnih stranaka. Da je negdje ostao vjeran, ako je mogao biti vjeran ikome osim sebi, tijekom godina sigurno bi se dočepao saborskoga mandata, što je jako želio, ali i to mu je bilo premalo.

${ }^{62}$ Slovenski gospodar slovenski je časopis koji je izlazio do 1867. do 1941. godine. Bio je to konzervativni katolički tjednik usmjeren na štajerski prostor.

${ }^{63}$ Domoljub je bio slovenski tjednik koji je izlazio od 1888. do 1944. godine. Objavljivao je jednostavne priloge namijenjene obrazovanju i zabavi uglavnom seljačkoga stanovništva, kojima je prenosio tradicionalne kršćanske vrijednosti (AMON, Vloga slovenskega časopisja, 18).

${ }^{64}$ ZADRAVEC, Miško Kranjec, 118.

${ }^{65}$ „Pavla Horvata je poznal, kakor so ga poznali skoraj vsi ljudje v Slovenskih goricah in po Prekmurju. Ni se spominjal, kje se je bil prvič srečal z njim, vedel je samo, da se tikata in da sta 'stara' znanca. Ta čudni, najbolj skrivnostni slovenski 'politik', je imel tedaj svojevrsten, in to ne majhen vpliv na nekatere ljudi. Bil je človek srednjih let, skoraj še mlad ali vsaj mladosten, s politiko pa se je ukvarjal že od one vojne, najprej po Prekmurju, kjer je bil doma, nato po Slovenskih goricah, kamor se je bil oženil k Mali Nedelji, in kjer je imel svojo hišo" (KRANJEC, Fara svetega Ivana, 246). 
U prvih deset godina nakon Prvoga svjetskog rata još nije mnogo značio u politici i nije bio poznat. Doživljavao je samo poraze, a osim politike bavio se i stvarima koje bi mu donijele novac. U Donjoj Lendavi bio je nekoliko puta u zatvoru zbog optužbi za različite kriminalne radnje, čak su mu pripisivali prodaju 'bijeloga roblja' u Južnu Ameriku. Ali sucima u Lendavi nikada se nije posrećilo da mu dokažu barem neku malenu stvar, iako su uvijek tvrdili da znaju sve o njemu. Kada se oženio i otišao iz Prekomurja u Slovenske gorice, imao je u štedionici pohranjene lijepe novce, barem za takva seljačkoga dečka dovoljno.”66

Kranjec optužuje Horvata za iskorištavanje malih, slabo obrazovanih i nedovoljno informiranih ljudi sa slovenskoga sela da bi se uzdigao na političkoj pozornici:

„Svoj je politički cilj naslutio tek u drugom desetljeću. U navali fašizma po Europi, lažnih revolucionarnih parola, borbe protiv komunizma te u pripremama za pohod na boljševičku Rusiju Pavle Horvat postao je aktivan. Njegov život bio je sama želja za slavom, vlasti te jedna laž. Bio je kao rođen za tajnovitoga i lažljivog revolucionara koji je kao čarobni duh lebdio nad Slovenskim goricama i Prekomurjem. Uvijek je bio na cesti ili negdje po selima. Dobro pamćenje ljudi vodilo ga je po svim krajevima i posvuda je imao poznanike. I dok je tražio put prema svim važnijim političarima te se sa svima upoznao, potporu je tražio među siromašnim ljudima, po Slovenskim goricama među vinogradskim radnicima, sitnim zemljoposjednicima i kmetovima, a u Prekomurju među sezonskim radnicima. Naime, mali ljudi, ljudi bijede i patnje, ljudi koji su morali svoju egzistenciju tražiti po svijetu i koji su željeli bilo kakav spas, oni su bili centar njegova 'pokreta'. I nigdje u Sloveniji nije bilo toliko malih, u nekom pogledu na sve spremnih ljudi kao u Slovenskim goricama i Prekomurju. Tu je uspijevao kao slak. Do Dravskoga polja, a još manje u druge krajeve Slovenije, njegov utjecaj nije dosezao." ${ }^{67}$

${ }^{66}$ „Njegova politika je hodila vedno po nekih stranskih poteh, dasi se je kaj rad vrtel okrog velikih pomembnih strank. Ce bi bil ostal kje zvest, ako bi komu razen sebi sploh mogel biti zvest, bi se v dolgih letih prav gotovo dokopal do poslanskega mandata, kar je zelo želel, toda tudi to mu je bilo premalo. $\mathrm{V}$ prvih desetih letih po prvi svetovni vojni politično še ni mnogo pomenil in tudi znan še ni bil. Doživljal je same poraze, pa se je poleg politike ukvarjal tudi s stvarmi ki naj bi mu prinesle denar. V Dolnji Lendavi so ga imeli nekajkrat v zaporih, da bi ga obsodili za razna kriminalna dejanja, celo prodajanje 'belega blaga' v Južno Ameriko so mu očitali. Toda sodnikom v Lendavi se nikdar ni posrečilo, da bi mu dokazali vsaj majhno stvar, dasi so vedno trdili, da vedo o njem vse. Ko se je oženil in se umaknil iz Prekmurja v Slovenske gorice, je imel v hranilnici naložen lep denar, vsaj za takega kmečkega fanta dovolj” (Isto, 246-247).

${ }^{67}$ „Svoj politični čas je zaslutil šele v drugem desetletju. V navalu fašizmov po Evropi, zlaganih revolucionarnih gesel, bojev proti komunizmu in v pripravah za pohod nad boljševičko Rusijo je Pavle Horvat postal nad vse delaven. Njegovo življenje je bila ena sama sla po slavi, oblasti in ena sama zlaganost. Bil je kar rojen za skrivnostnega iz zlaganega revolucionarja, ki je kako čaroben duh legal na Slovenske gorice in nad Prekmurje. Bil je vedno na cesti ali kje po vaseh. Dober spomin za ljudi ga je vodil po vseh krajih in povsod je imel znance. Medtem ko je navzgor iskal poti do vseh vidnejših politikov in se $z$ vsemi poznal, je navzdol iskal zaslombe, med revnimi ljudmi, po Slovenskih goricah med viničarji, želarji, malimi kmeti, v Prekmurju pa med sezonskimi delavci. Skratka mali ljudje, ljudje bede in trpljenja, ljudje ki so morali po svetu in ki so si želeli kakršnega koli odrešenja, ti so bili jedro njegovega 'pokreta'. In nikjer v Sloveniji ni toliko malih, v nekem pogledu na vse pripravljenih malih ljudi, kakor v Slovenskih goricah in 
Iz dijelova teksta koje je Kranjec posvetio karakterizaciji njegova lika može se zaključiti da je svoje djelovanje temeljio na slovensko-hrvatskim odnosima, pri čemu je veliku ulogu u njegovoj afirmaciji imala upravo Hrvatska:

„U svojem političkom planiranju na slovenske se stranke uopće nije oslanjao. Shvatio je da ga ni klerikalci ni liberali neće pustiti bliže i dati mu važniju ulogu. Samo je jedno bilo moguće: srušiti obje priznate vodeće slovenske stranke te preuzeti sve to u svoje ruke. A to je pak bilo moguće s tuđom pomoći. Takvu tuđu pomoć vidio je u Zagrebu.

Zagreb je za njega bilo čaroban grad. Dok je Ljubljanu gotovo zaboravio te ju je mrzio, Zagreb je sve više postajao njegov dom. I preko Zagreba - svoje velike snove! - pokušao je ostvariti u Ljubljani!" ${ }^{68}$

Horvat je dakle u romanu prikazan kao proizvod hrvatsko-slovenskih odnosa i potrebe obaju naroda da na neki način reagiraju na aktualnu predratnu političku i društvenu situaciju:

„U Zagrebu su trebali slovensku pomoć. Protiv Beograda su sami bili preslabi, prije svega zato što bi slovenska politika obično zaobišla Zagreb te tražila oslonac u Beogradu. Kako bilo da bilo, Horvatu se posrećilo te je u Zagrebu već prije izbora 1938. imao nešto potpore. Iako je u Sloveniji bio potpuno nevažan, istina je da se u Zagrebu uspio približiti vodećim hrvatskim političarima, i to samo zato što su ga u Sloveniji izigrali na izborima, gdje se i kandidirao. Tada se u trenutačnom bijesu ponudio stranci Jugoslavenska radikalna zajednica te se prodao, ni manje ni više, za kakvih jadnih pet tisuća dinara, a da za njegovu izdaju u Zagrebu nisu ni znali. Nakon izbora okrenuo se Zagrebu s još većim žarom.”9

v Prekmurju. Tu je uspeval kakor slak. Medtem ko na Dravsko polje, še manj pa po drugih krajih Slovenije njegov vpliv ni segal" (Isto, 247).

68, ,V svojem političnem snovanju se na slovenske stranke sploh ni naslanjal. Sprevidel je, da ga niti klerikalci niti liberalci nočejo pustiti bliže in mu dati vidnejše vloge. Samo eno je bilo mogoče: zrušiti obe priznani slovenski vodilni stranki in prevzeti vse v svoje roke. A to spet je bilo mogoče s tujo pomočjo. Tako tujo pomoč je videl za zdaj v Zagrebu. Zagreb je bil zanj čarobno mesto. Medtem ko Ljubljane skorajda ni poznal in jo je sovražil, je bil v Zagrebu čedalje bolj doma. In prek Zagreba - njegove velike sanje! - je skušal osvojiti Ljubljano!” (Isto).

${ }^{69}$ „V Zagrebu so potrebovali slovenske pomoči. Proti Beogradu so bili sami preslabotni, celo pa, ker je slovenska politika navadno obšla Zagreb in iskala v Beogradu zaslombe. Kakor koli se je posrečilo Horvatu, v Zagrebu je že pred volitvami 1938. leta imel dokaj zaslombe. Naj je takrat v Sloveniji bil še tako nepomemben, resnica je, da mu je v Zagrebu uspelo približati se vodilnim hrvatskim politikom, in le zato, ker so ga v Sloveniji izigrali, pri tistih volitvah ni kandidiral. Takrat se je $\mathrm{v}$ trenutni jezi šel ponujat stranki JRZ in se prodal za nič manj, a tudi nič več kakor borih pet tisoč dinarjev, ne da bi za njegovo izdajstvo v Zagrebu izvedeli. Po volitvah pa se je s še večjo vnemo zatekel v Zagreb" (Isto). 


\section{Zaključak}

Promatrajući podatke objavljene o Pavlu Horvatu u znanstvenim i stručnim radovima te na osnovi novinskih napisa, iz njegova djelovanja vidljive su dvije temeljne slike o njemu. Prva se odnosi na početke njegova javnoga i političkoga djelovanja i pokazuje mladića koji želi aktivno sudjelovati u aktualnim političkim zbivanjima u Sloveniji, ali zbog različitih razloga, a prije svega vjerojatno vlastitoga pristupa, to mu ne uspijeva. Druga je slika mnogo intenzivnija i prikazuje trenutke iz Horvatova života koji ga ne prikazuju u pozitivnom svjetlu, nego kao negativca koji u javnosti stvara lažnu predodžbu o sebi. Na temelju prikupljenih podataka i prvu i drugu sliku teško je u cijelosti upotpuniti te je svakako potrebno još istraživačkoga rada da bi se odgovorilo na sva pitanja. Podaci dobiveni iz dnevnoga tiska parcijalni su kao i podaci dobiveni iz dokumenata.

Druga slika koja se dobiva iz prikupljenih podataka temeljno je polazište za oblikovanje književnoga lika Pavla Horvata u romanu Fara sv. Ivana Miška Kranjca. U njemu je Horvatov lik prikazan kao negativna osoba koja se, u prvom redu, bori za svoje interese pod krinkom brige za Slovence u Hrvatskoj. Takvo književno oblikovanje svoje utemeljenje može imati u dokumentima i novinskim napisima koji su autoru bili dostupni, ali može se zasnivati i na osobnom dojmu koji je Kranjec stekao s obzirom na to da je izvjesno da je Horvata osobno poznavao i stoga ga ovjekovječio u svojem romanu. Iako je danas Pavle Horvat u slovenskoj i hrvatskoj historiografiji gotovo nepoznat, upravo književno oblikovanje njegova lika potiče na promišljanje manje poznatih slovensko-hrvatskih političkih odnosa u međuratnom razdoblju, a posebice tijekom Drugoga svjetskog rata.

\section{Objavljeni izvori i tisak}

Ameriška domovina (Cleveland), 1948.

Dolenjski list (Novo Mesto), 1954.

Domovina (Ljubljana), 1930.

Domovina in Kmetijski list (Ljubljana), 1941.

Glasilo KSK jednote (Toronto), 1922.

Jutro (Ljubljana), 1930, 1940-1941.

Karawanken Bote (Krainburg = Kranj), 1941.

Mariborski delavec (Maribor), 1919.

Mariborski večernik „Jutra” (Maribor), 1940.

Murska straža (Gornja Radgona), 1922-1923.

Novine (Murska Sobota), 1920, 1922-1923, 1929.

Ponedeljski Slovenec (Ljubljana), 1938.

Slovenec (Ljubljana), 1921, 1940-1941. 
Slovenska zemlja (Ljubljana), 1940.

Slovenski dom (Ljubljana), 1940.

Tabor (Maribor), 1924.

Večernik (Ljubljana), 1940.

\section{Literatura}

AMON, Smilja. „Vloga slovenskega časopisja v združevanju in ločevanju slovenske javnosti od 1797. do 1945." U: Prispevki k zgodovini slovenskih medijev, ur. Maruša Pušnik. Ljubljana: Fakulteta za družbene vede, 2008, 9-24.

GANTAR GODINA, Irena. „Slovenski intelektualci - izseljenci na Hrvaškem: Jernej Francelj (1821-1889)". Dve domovini. Razprave o izseljenstvu (2004), br. 19: 165-183.

GANTAR GODINA, Irena. „Slovenski izobraženci na Hrvaškem od 1850 do 1960". Dve domovini. Razprave o izseljenstvu (2004), br. 20: 77-94.

GANTAR GODINA, Irena. „Slovenski izobraženci na Hrvaškem po letu 1868: Ivan Steklasa”. Dve domovini. Razprave o izseljenstvu (2006), br. 24: 153166.

HEĆIMOVIĆ, Branko; BARBIERI, Marija; NEUBAUER, Henrik. Slovenski umjetnici na hrvatskim pozornicama = Slovenski umetniki na hrvaških odrih . Zagreb: Slovenski dom; Vijeće slovenske nacionalne manjine Grada Zagreba = Svet slovenske nacionalne manjšine Mesta Zagreba, 2011.

ILEŠIČ, Svetozar. „Novi prispevki k proučevanju socialnih problemov slovenske vasi”. Ljubljanski zvon 59 (1939), br. 3: 185-187.

JURIĆ, Mirjana. „Zagreb u Prvom svjetskom ratu: povijesne novine kao izvor za istraživanje socijalne povijesti”. Libellarium 2 (2009), br. 2: 121-144.

KARAKAŠ OBRADOV, Marica. „Migracije Slovencev na hrvaško območje v drugi svetovni vojni (izseljevanje in izgnanstvo)". Prispevki za novejšo zgodovino 52 (2012), br. 2: 139-174.

KARAKAŠ OBRADOV, Marica. Novi mozaici nacija u „novim poredcima”. Migracije stanovništva na hrvatskom području tijekom Drugoga svjetskog rata $i$ poraća. Zagreb: Hrvatski institut za povijest, 2014.

„Kocbek, Edvard“. Hrvatska enciklopedija, mrežno izdanje, Leksikografski zavod Miroslav Krleža, 2018. Pristup ostvaren 27. 11. 2018. http://www.enciklopedija.hr/natuknica.aspx?id=32164

KRANJEC, Miško. Fara svetega Ivana. Ljubljana: Slovenski knjižni zavod v Ljubljani, 1947.

KRIZMAN, Bogdan. Ustaše i Treći Reich, sv. 1. Zagreb: Globus, 1986.

KRŽIŠNIK-BUKIĆ, Vera. „Znameniti Slovenci na Hrvaškem skozi zgodovino". Migracijske i etničke teme 22 (2006), br. 4: 421-445.

KUZMIČ, Franc. „Stranke v Prekmurju med obema vojnama”. Kronika. Časopis za slovensko krajevno zgodovino 39 (1991), br. 1-2: 58-63. 
MLAKAR, Boris. „Nekaj podatkov k razjasnitvi stikov med slovenskim protirevolucionarnim vodstvom in Zagrebom ob koncu druge svetovne vojne”. Prispevki za novejšo zgodovino 52 (2012), br. 1: 141-150.

MLAKAR, Boris. „Ustaši in slovenska protirevolucija”. Borec. Revija za zgodovino, literaturo in antropologijo 34 (1984), br. 5: 361-371.

PELEŠ, Gajo. Tumačenje romana. Zagreb: ArTresor naklada, 1999.

PERŠAK, Katja. „Anton Korošec in slovensko-hrvaška nasprotja v Prekmurju”. Pilar. Časopis za društvene i humanističke studije IV (2009), br. 7-8 (1-2): 133-150.

PLAHUTA, Slavica. „Koprivec, Ignac”. Slovenska biografija, Slovenska akademija znanosti in umetnosti, Znanstvenoraziskovalni center SAZU, 2013. Pristup ostvaren 27. 11. 2018. http://www.slovenska-biografija.si/oseba/ sbi1015120/\#primorski-slovenski-biografski-leksikon.

PRUNK, Janko. „Radić in Slovenci 1919-1928”. Zgodovinski časopis 39 (1985), br. 1-2: 25-34.

RIMAN, Barbara. „Slovenska društva u Hrvatskoj između dva svjetska rata (1918. - 1941.)". Časopis za suvremenu povijest 46 (2014), br. 1: 101-130.

ROZMAN, Boris. „Orlovski odsek na Vrhniki (1908-1929)”. Kronika. Časopis za slovensko krajevno zgodovino 41 (1993), br. 3: 165-175.

SLODNJAK, Anton. Slovensko slovstvo. Ljubljana: Mladinska knjiga, 1968.

ŠLEBINGER, Janko. „Klekl, Jožef”. Slovenska biografija, Slovenska akademija znanosti in umetnosti, Znanstvenoraziskovalni center SAZU, 2013. Pristup ostvaren 27. 11. 2018. https://www.slovenska-biografija.si/oseba/ sbi275376/.

ŠULIGOJ, Ljubica. „Socialni pravičnosti posvečeno življenje in delo: ob 90-letnici Jožeta Kerenčiča in Ivana Potrča ter 100-letnici dr. Jožeta Potrča”. Časopis za zgodovino in narodopisje 74 (2003), br. 3-4: 373-390.

VIDOVIČ-MIKLAVČIČ, Anka. „Zveza slovenskih kmetov v letih 19321935”. Zgodovinski časopis 43 (1989), br. 4: 555-569.

VURNIK, France. „In memoriam: Ignac Koprivec”. Sodobnost 29 (1981), br. 2: 129-131.

ZADRAVEC, Franc. Miško Kranjec 1908-1983. Ljubljana: Prešernova družba, 2007.

ŽEBOVEC, Marjeta. Slovenski književniki rojeni do leta 1899. Ljubljana: Karantanija, 2005.

ŽIDOVEC, Vladimir. Pavelićev diplomat na jugoistoku Europe. Bjelovar: Tiskara Horvat, 2017. 


\section{SUMMARY}

\section{Pavle Horvat in the Context of Slovenian-Croatian Political Relati- ons from 1918 to 1945 and his Literary Treatment}

Examining the data on Pavle Horvat published on the basis of scientific and professional papers as well as newspaper articles shows two basic views of his work. The first involves the beginnings of his public and political activity, and concerns a young man who wished to actively participate in the then current political events in Slovenia but, for various reasons, most of all probably his approach, failed. The second view is much more intense and focuses on moments from Horvat's life that do not show him in a positive light, but as a "bad guy" who created a false public image of himself. Based on the gathered data, it is difficult to complete both images and it is certainly necessary to conduct more research in order to answer all questions. The data gleaned from the daily press is partial, as is the data from the documents.

The second image, which can be seen from the gathered data, serves as the basis for forming the literary character of Pavle Horvat in the novel Fara sv. Ivana (The Parish of St John) by Miško Kranjec. In it, Horvat's character is showed in a negative light, as a person who primarily fights for his personal interests under the guise of caring for Slovenians in Croatia. Such a literary formation may be based on documents and newspaper articles that were available to author Miško Kranjec, but could also be based on Kranjec's subjective opinion, since it is obvious he knew Horvat personally and therefore immortalised him in his novel. Even though the character of Pavle Horvat is today almost unknown in Slovenian and Croatian historiography, it is precisely the literary formation of his character that prompts us to think about the lessknown Slovenian-Croatian political relations in the interwar period and especially during World War II.

Key words: Pavle Horvat; Slovenians in Croatia; World War II; Miško Kranjec 